\title{
Studies on the In Vitro Antioxidant Activity of Laportea Aestuans Leaf Extract
}

\author{
*Okereke, S.C and Elekwa, I \\ Department of Biochemistry, Faculty of Biological \& Physical Sciences, Abia State University, Uturu, Nigeria.
}

\begin{abstract}
Hydro - ethanolic leaf extract of Laportea aestuans L. was screened for antioxidant activity using various antioxidant models such as 1,1-diphenyl-2-picryl hydroxyl quenching (DPPH) assay, superoxide scavenging assay $\left(\mathrm{O}_{2}^{o o}\right)$, reducing power capacity $(\mathrm{RC})$, scavenging capacity towards hydroxyl ion $\left(\mathrm{OH}^{\circ}\right)$ radical, nitric oxide $\left(\mathrm{NO}^{\circ}\right)$ radical inhibition, hydrogen peroxide inhibition activity $\left(\mathrm{H}_{2} \mathrm{O}_{2}\right)$, lipid peroxidation (LPO) inhibition activity and 2,2'-azinobis-3-ethylbenzothiozolin-6-sulfonic acid $\left(\mathrm{ABTS}^{\text {o+ }}\right)$ cation decolourization test. Total phenolic content, total flavonoid content and ascorbic acid content were also determined. The leaf extract of L. aestuans (LAE) yielded $199.3 \pm 4.041 \mathrm{mg}$ Gallic acid/100g of sample as the total phenolic content, $90.7 \pm 6.807 \mathrm{mg}$ Quercetin/100g of sample as total flavonoid content and $52.0 \pm 5.000 \mathrm{mg}$ vitamin/100g of sample as ascorbic acid content. The extract exhibited high scavenging activity against DPPH, $\mathrm{O}_{2}, \mathrm{OH}, \mathrm{NO}, \mathrm{H}_{2} \mathrm{O}_{2}, \mathrm{ABTS}$ and Lipid peroxide ( $\mathrm{LPO}$ ) with $\mathrm{IC}_{50}$ values of $15.0 \pm 1.00,247.0 \pm 4.58,84.3 \pm 3.79$, $67.3 \pm 3.06,230.7 \pm 7.02,81.0 \pm 3.61$ and $82.7 \pm 6.43 \mu \mathrm{g} / \mathrm{ml}$ respectively. Correlation was high between polyhenolic content and antiradical potential of different reactive oxygen species indicated that polyphenols are considered as main antioxidants.
\end{abstract}

Key words: Laportea aestuans, Antioxidant activity, DPPH, Reducing capacity, ABTS, Nitric oxide and Antiradical activity

\section{Introduction}

Antioxidants are found useful in the prevention and treatment of many human diseases such as cardiovascular diseases, cancer, inflammation and aging related disorders which originate from free radical derived oxidative stress [1]. Natural antioxidant mechanisms can be inefficient; hence dietary intake of antioxidant compounds becomes important [2]. Studies have indicated that relationship exist between the plant antioxidants and reduction of chronic diseases [3]. These benefits are believed to result from the antioxidant components of plant origin, vitamins, flavonoids and carotenoids. Recent studies have shown that polyphenols in plants scavenge reactive oxygen species and effectively prevent oxidative cell damage [4].

Laportea aestuans belongs to the family Urticaceae which is composed of 22 species. Two species have so far been reported for Southern Nigeria. They include Laportea aestuans (Linn) Chew and Laportea ovilifolia (Schumach) Chew (male and female) [5].

Laportea aestuans is an annual herbaceous weed around waste places. The stem is erect, angular, covered with pilose hair or stinging hairs and green in colour [6]. In Gabon, Nigeria and Ghana the cooked leaves of

Laportea aestuans are eaten as vegetables [7,8].

In West Africa, the plant finds application in ethnomedicine, in the treatment and management of headache, diuretic to cure blenorrhoea and chest problems. It is also used to deliver placenta after child birth, prevent excessive menstrual bleeding. Extracts are used to treat arthritis, anemia, hayfever, kidney problems and pain [9].

In the present study, antioxidant activity of hydro ethanolic extract of leaves of Laportea aestuans has been evaluated, employing different indices of antioxidant assays.

\section{Plant material:}

\section{Materials And Methods}

The leaves of Laportea aestuans (Stinging nettle) were harvested fresh from the botanic garden of Abia State University, Uturu, Nigeria and identified by Dr. S.K Chukwuka of the Plant Science Department of Abia State University. Voucher specimen was deposited in the herbarium of the Abia State University (Voucher no: ABSU 125).

\section{Preparation of Laportea aestuans Leaf Extract (LAE)}

The leaves of L. aestuans were air dried at room temperature and ground to fine powder. 1000g of the leaf powder was extensively extracted with $500 \mathrm{ml}$ distilled water ethanol mixture $98 \%$ [1:1(w/v)] for 10 hours, using Soxhlet apparatus. The extract was centrifuged (3000xg) thrice and the clear supernatants were filtered over Whatman No. 1 filter paper. The extract was evaporated to dryness by rotary flash evaporator (Buchi type, 
Switzerland) under reduced pressure at $45^{\circ} \mathrm{C}$. Different concentrations were prepared from the resultant crude hydro ethanolic extract to determine in vitro antioxidant capacity.

\section{Determination of Total Phenolic (TP) Content}

The total phenolic content was determined using Folin - Ciocalteu method [10]. $1 \mathrm{ml}$ of diluted extract was mixed with diluted Folin - Ciocalteu reagent $(1 \mathrm{~N} .1 \mathrm{ml})$. The mixture is allowed to react for $3 \mathrm{~min}$ at room temperature. The absorbance was read at $765 \mathrm{~nm}$ using UV - Visible Spectrophotometer (Shimadzu, Kyoto, Japan). The analysis was done in triplicate. The TPC was expressed as $\mathrm{mg}$ gallic acid equivalent from gallic acid standard curve (mg GAE/100g fresh material $\left.\mathrm{R}^{2}=0.9968\right)$.

\section{Measurement of Total Flavonoid (TFC)}

The content of total flavonoid iin L. aestuans leaf extract was based on the [11] method. $0.5 \mathrm{ml}$ of $2 \%$ $\mathrm{AlCl}_{3}$ ethanol solution was measured after 1 hour at room temperature using UV - Visible spectrophotometer (Shimadzu, Kyoto, Japan). The TFC was determined from a quercetin standard curve and the results were expressed as ( $\mathrm{mg}$ quercetin equivalent $\mathrm{mg} \mathrm{QE} / 100 \mathrm{~g}$ fresh material $\mathrm{R}^{2}=0.992$ ).

\section{Measurement of Ascorbic Acid (AA)}

The amount of ascorbic acid is estimated using the method of [12]. $5 \mathrm{ml}$ of the standard solution of Vitamin C were taken into $100 \mathrm{ml}$ conical flask. $10 \mathrm{ml}$ of $4 \%$ oxalic acid was added and titrated against the dye. Pink colour that appears and persists for few minutes signifies end point. The amount of the dye consumed is equivalent to the amount of ascorbic acid. Extract the sample ( $0.5-5 \mathrm{~g}$ depending on sample) in $4 \%$ oxalic acid and make up to a known volume $(100 \mathrm{ml})$ and centrifuge. A volume of $5 \mathrm{ml}$ of the supernatant and $100 \mathrm{ml}$ of $4 \%$ oxalic acid were taken and titrated against the dye. Amount of ascorbic acid was calculated and expressed as $\mathrm{mg} / 100 \mathrm{~g}$ sample.

\section{Antioxidant Activity Determination}

The antioxidant activity of hydro - ethanolic extract was evaluated using DPPH radical quenching assay, reducing capacity, scavenging capacity towards hydroxyl ion $\left(\mathrm{OH}^{\circ}\right)$ radicals, scavenging capacity towards nitric oxide $\left(\mathrm{NO}^{\circ}\right)$, ABTS ${ }^{\circ+}$ cation decolorization test, hydrogen peroxide $\left(\mathrm{H}_{2} \mathrm{O}_{2}\right)$ scavenging capacity and lipid peroxidation assay TBARS.

\section{DPPH Radical Quenching Activity}

DPPH radical scavenging activity was adopted from those previously described with slight modification [13]. Various concentrations $(20-100 \mu \mathrm{g} / \mathrm{ml})$ of sample were mixed with $5 \mathrm{ml}$ of $0.1 \mathrm{mM}$ ethanol solution of DPPH and vortexed. The tubes were allowed to stand at room temperature for 20min. the control was prepared as above without any extract and ethanol was used for the baseline correction. Changes in the absorbance of the samples were measured at $517 \mathrm{~nm}$. Mean values were obtained from triplet experiments. Butylated hydroxyl toluene (BHT) was taken as reference standard. The percentage quenching of DPPH was calculated as follows:

Inhibition of DPPH $(\%)=$ Control $517 \mathrm{~nm}-$ Sample $517 \mathrm{~nm} \quad$ X 100

\section{Control $517 \mathrm{~nm}$}

Where sample $517 \mathrm{~nm}$ was absorbance of the sample and control $517 \mathrm{~nm}$ was absorbance of control. The results were expressed as IC50, which means the concentration at which $\mathrm{DPPH}^{\circ}$ radical were quenched by $50 \%$.

\section{Reducing Capacity}

The ferric reducing power of the leaves of $L$. aestuans extract was quantified according to the method of [14]. Different concentrations of the extract $(200-1000 \mu \mathrm{g} / \mathrm{ml})$ were prepared. To all the extracts in test tubes $2.5 \mathrm{ml}$ of sodium phosphate buffer followed by $25 \mathrm{ml}$ of $1 \%$ potassium ferricyanide $\left[\mathrm{K}_{2} \mathrm{Fe}(\mathrm{CN})_{6}\right]$ solution was added. The contents were vortexed well and incubated at $50^{\circ} \mathrm{C}$ for 20 mins. After incubation, $2.5 \mathrm{ml}$ of $10 \%$ trichloroacetic acid (TCA) was added to all the tubes and centrifuged at $3000 \mathrm{~g}$ for $10 \mathrm{mins}$. Afterwards, to $5 \mathrm{ml}$ of the supernatant, $5 \mathrm{ml}$ of deionized water was added. To this about $1 \mathrm{ml}$ of $1 \%$ ferric chloride was added to each test tube and incubated at $35^{\circ} \mathrm{C}$ for 10 mins. The absorbance was read at $700 \mathrm{~nm}$. Mean values were obtained from triplet experiments.

The reducing power of the extract was linearly proportional to the concentration of the sample. Increased absorbance of the reaction mixture indicated increased reducing power. Butylated hydroxyl toluene (BHT) was taken as reference standard. 


\section{Scavenging Capacity towards Superoxide Radical $\left(\mathrm{O}_{2}{ }^{\circ}\right)$}

Superoxide anion radical $\left(\mathrm{O}_{2}{ }^{\circ}\right)$ generated in the phenazine methosulfate - reduced form of nicotinamide adenine dinucleotide (PMS - NADH) system by oxidation of NADH and assayed by the reduction of nitro blue tetrazolium chloride (NBT) by the extract with some changes [15].

The $\mathrm{O}_{2}{ }^{\circ}$ were generated in $1.25 \mathrm{ml}$ of Tri $-\mathrm{HCl}(16 \mathrm{mM}$, pH 8.0), $0.25 \mathrm{ml}$ of NBT $(150 \mu \mathrm{M}), 0.25 \mathrm{ml}$ of NADH $(468 \mu \mathrm{M})$ and different concentrations $(100-1000 \mu \mathrm{g} / \mathrm{mg})$ of LAE and standard. The reaction was initiated by addition of $0.25 \mathrm{ml}$ of Phenazine methosulfate $(60 \mu \mathrm{M})$ to the mixture. Following incubation at ambient temperature for $5 \mathrm{mins}$, the absorbance was read at $560 \mathrm{~nm}$. Blank was used as the same was using ethanol instead of sample. BHT was used for comparison. The percentage scavenging of $\mathrm{O}_{2}{ }^{\circ}$ was calculated as follows: Inhibition of $\mathrm{O}_{2}{ }^{\circ}(\%)=$ Control 560nm - Sample 560nm X 100

\section{Control 560nm}

Where sample $560 \mathrm{~nm}$ was absorbance of sample and control $560 \mathrm{~nm}$ was absorbance of control. $\mathrm{IC}_{50}$ was calculated at 50\% reduction in absorbance brought about by sample compared with blank.

\section{Scavenging Capacity towards Hydroxyl ion $\left(\mathrm{OH}^{0}\right)$ Radical}

The $\mathrm{OH}^{\mathrm{o}}$ scavenging activity of the LAE was determined according to the method described by Kleim et al, (1981). Different concentrations $(50-250 \mu \mathrm{g} / \mathrm{ml})$ of extract were added with $1.0 \mathrm{ml}$ of iron - EDTA solution $(0.13 \%$ ferrous ammonium sulfate and $0.26 \%$ EDTA), $0.5 \mathrm{ml}$ of EDTA solution $(0.018 \%)$, and $1.0 \mathrm{ml}$ of DMSO $(0.85 \% \mathrm{v} / \mathrm{v}$ in $0.1 \mathrm{M}$ phosphate buffer, $\mathrm{pH} 7.4)$. the reaction was started by adding $0.5 \mathrm{ml}$ of ascorbic acid $(0.22 \%)$ and incubated at $80-90^{\circ} \mathrm{C}$ for 15 mins in a water bath. The reaction was terminated by the addition of $0.1 \mathrm{ml}$ of icd - cold TCA $(17.5 \% \mathrm{v} / \mathrm{v})$. the milliliters of Nash reagent $(75.0 \mathrm{~g}$ of ammonium acetate, $3.0 \mathrm{ml}$ of glacial acetic acid and $2 \mathrm{ml}$ of acetyl acetone were mixed and raised to $1 \mathrm{~L}$ with distilled water), was added and left at room temperature for $15 \mathrm{mins}$. The intensity of the colour formed was measured at $412 \mathrm{~nm}$ against reagent blank. The hydroxyl radical scavenging reference standard was also used for comparison. The radical scavenging activity was calculated by the following formular:

HRSA $(\%)=1-$ difference in absorbance of sample X 100

$$
\text { Difference in absorbance of blank }
$$

\section{Scavenging Capacity towards Nitric Oxide (NO)}

Sodium nitroprusside (SNP) in aqueous solution at physiological $\mathrm{pH}$ spontaneously generates nitric oxide, which interacts with oxygen to produce nitrite ions, which can be estimated by the use of Griss Illosvoy reaction [17]. Scavengers of nitric oxide compete with oxygen leading to reduced production of nitric oxide. The reaction mixture $(3 \mathrm{ml})$ containing SNP $(10 \mathrm{nM}, 2 \mathrm{ml})$ phosphate buffer saline $(0.5 \mathrm{ml})$ and the LAE at different concentrations and standard $(50-250 \mu \mathrm{g} / \mathrm{ml})$ were incubated at $25^{\circ} \mathrm{C}$ for $15 \mathrm{mins}$. After incubation, $0.5 \mathrm{ml}$ of the incubated solution containing nitrite was pipette and mixed with $1 \mathrm{ml}$ of sulfanilic acid reagent ( $0.33 \%$ in $20 \%$ glacial acetic acid) and allowed to stand for $5 \mathrm{mins}$ for completing diazotization, then, $1 \mathrm{ml} \mathrm{of} \mathrm{N-}$ 1 -naphthyl ethylene diamine at $25^{\circ} \mathrm{C}$. The absorbance was measured at $540 \mathrm{~nm}$. BHT was used for comparison. The percentage scavenging of $\mathrm{NO}$ was calculated as follows:

Inhibition of NO $(\%)=$ Control 540nm - Sample 540nm X 100

Control $540 \mathrm{~nm}$

Where sample 540nm was absorbance of the sample and control 540nm was absorbance of control.

\section{Hydrogen Peroxide $\left(\mathrm{H}_{2} \mathrm{O}_{2}\right)$ Scavenging Activity}

The hydrogen peroxide scavenging activity of the extract was determined by the method of [18]. The extract at different concentrations $(100-500 \mu \mathrm{g} / \mathrm{mg})$ was dissolved in $3.4 \mathrm{ml}$ of $0.1 \mathrm{M}$ solution of $\mathrm{H}_{2} \mathrm{O}_{2}$. The absorbance value of the reaction mixture was recorded at $230 \mathrm{~nm}$ and BHT was considered as the standard. The percentage scavenging of $\mathrm{H}_{2} \mathrm{O}_{2}$ was calculated as follows:

Inhibition of $\mathrm{H}_{2} \mathrm{O}_{2}(\%)=$ Control 230nm - Sample 230nm X 100

Control $230 \mathrm{~nm}$

Where, sample 230nm was absorbance of sample and control 230nm was the absorbance of control.

\section{2,2' - Azinobis (3-ethylbenzothiazoline sulphonic acid) $\left(\mathrm{ABTS}^{\mathbf{0}}\right)$ Cation Decolouration Test}

The $\mathrm{ABTS}^{\mathrm{ot}}$ radical cation was produced by oxidizing $\mathrm{ABTS}^{\mathrm{ot}}$ with potassium persulphate $\left(\mathrm{K}_{2} \mathrm{~S}_{4} \mathrm{O}_{8}\right)$ [19]. The solution (7mM) was oxidized with $\mathrm{K}_{2} \mathrm{~S}_{4} \mathrm{O}_{8}(2.4 \mathrm{mM})$ for 12 hours at room temperature in the dark. The $\mathrm{ABTS}^{\mathrm{ot}}$ solution was then diluted by mixing $990 \mu \mathrm{ABTS}{ }^{\mathrm{ot}}$ solution with $60 \mathrm{ml}$ ethanol to obtain an absorbance of $0.706 \pm 0.001$ at $734 \mathrm{~nm}$. LAE and BHT at various concentrations $(100-500 \mu \mathrm{g} / \mathrm{ml})$ were allowed to react with $1.0 \mathrm{ml}$ of the $\mathrm{ABTS}^{0+}$ solution and absorbance was measured at $734 \mathrm{~nm}$. After $7 \mathrm{mins}$ BHT was added for comparison. Percentage inhibition was calculated as $\mathrm{ABTS}^{\mathrm{ot}}$ radical scavenging activity

$$
=\text { Control } 734 \mathrm{~nm}-\text { Sample } 734 \mathrm{~nm} \quad \text { X } 100
$$




\section{Control 734nm}

Where, sample 734nm was absorbance of the sample and control 734nm was absorbance of control.

\section{Lipid Peroxidation (LPO) Assay}

A modified thiobarbituric acid - reactive species (TBARS) assay was used to measure the lipid peroxide formed using egg yolk homogenate as lipid rich medium [20]. Malondialdehyde (MDA), a secondary end product of oxidation of polyunsaturated fatty acids. Thiobarbituric acid (TBA) yielding a pinkish red chromogen with an absorbance maximum at $532 \mathrm{~nm}$. Egg homogenate $(0.5 \mathrm{ml}$ of $10 \% \mathrm{v} / \mathrm{v})$ and $0.1 \mathrm{ml}$ of extract were added to a test tube and made up to $1 \mathrm{ml}$ with distlled water. $0.005 \mathrm{ml}$ of $\mathrm{FeSO}_{4}(0.07 \mathrm{M})$ was added to induce lipid peroxidation and incubated for 30mins. Then $1.5 \mathrm{ml}$ of $20 \%$ acetic acid $(\mathrm{pH} 3.5), 1.5 \mathrm{ml}$ of $(\mathrm{w} / \mathrm{v})$ TBA $(0.8 \%)$ in $1.1 \%$ sodium dodecyl sulfate (SDS) and $0.5 \mathrm{ml}$ TCA $(20 \%)$ were added. The resulting mixture was votexed and then heated at $95^{\circ} \mathrm{C}$ for 60 mins. After cooling, $5.0 \mathrm{ml}$ of butn-n-ol was added to each test tube and centrifuged at $3000 \mathrm{rpm}$ for $10 \mathrm{mins}$. The absorbance of the organic upper layer was read at $532 \mathrm{~nm}$.

Inhibition of lipid peroxidation by the extract was calculated according to:

$$
\frac{1-\mathrm{E}}{\mathrm{C}} \times 100
$$

Where, $\mathrm{C}$ is the absorbance value of the fully oxidized control and $\mathrm{E}$ is the (Abs $532=\mathrm{TBA}-\mathrm{Abs} 532-\mathrm{TBA}$ ).

\section{STATISTICAL ANALYSIS OD DATA}

The experimental data were expressed as mean \pm SD of 3 independent measurements. Linear regression analysis was used to calculate the inhibition concentration $\left(\mathrm{IC}_{50}\right)$ values. One way analysis of variance (ANOVA) and Tukeys's multiple range tests were carried out. The P values less than 0.05 were adopted as statistically significant. Regression analysis was used to determine correlation between the antioxidant properties and polyphenolic content. GraphPad Prism (Version 6.0) was the software used for the statistical analysis.

\section{Results And Discussion}

Table 1showed the results of total phenolic compound, total flavonoids and ascorbic acid content of hydro - ethanolic leaf extracts of $L$. aestuans. Total phenolic content was found to be $199.3 \pm 4.041 \mathrm{mg} / 100 \mathrm{~g}$ of Gallic acid equivalent (GAE), the total flavonoids content was $90.7 \pm 6.807 \mathrm{mg} / 100 \mathrm{~g}$ of quercetin equivalent $(\mathrm{QE})$, whereas the ascorbic acid content was found to have $52.0 \pm 5.00 \mathrm{mg} / 100 \mathrm{~g}$ of Vitamin C equivalent. The antioxidant activity of phenolic compounds is mainly due to their redox properties, which allow them to act as reducing agents, hydrogen donors and singlet oxygen quenchers [21]. Polyphenols are present in a variety of plants utilized as important components of both humans and animal diets [22].

Table 1: Polyphenols and ascorbic acid content of $L$. aestuans leaf extract.

\begin{tabular}{ll}
\hline Parameters & $\mathrm{Mg} / 100 \mathrm{~g}$ \\
\hline Total Phenols $^{\mathrm{a}}$ & $199.3 \pm 4.041$ \\
Total Flavonoid $^{\mathrm{b}}$ & $90.7 \pm 6.807$ \\
Ascorbic acid $^{\mathrm{c}}$ & $52.0 \pm 5.00$ \\
\hline
\end{tabular}

Each value in the table was obtained by calculating the average of three experiments \pm standard deviation $(\mathrm{n}=$ 3). ${ }^{\mathrm{a}} \mathrm{mg}$ Gallic acid/100g of sample. ${ }^{\mathrm{b}} \mathrm{mg}$ Quercetin/100g of sample. ${ }^{\mathrm{c}} \mathrm{mg}$ Vitamin $\mathrm{C} / 100 \mathrm{~g}$ of sample.

The hydro - ethanolic extract of leaves of $L$. aestuans was tested for their antioxidant properties in a range of in vitro assays to determine their ability to scavenge reactive oxygen species (ROS). The extract exhibited a concentration - dependent antiradical activity by quenching DPPH radical and the DPPH scavenging activity was comparable to that of BHT (Fig.1). 


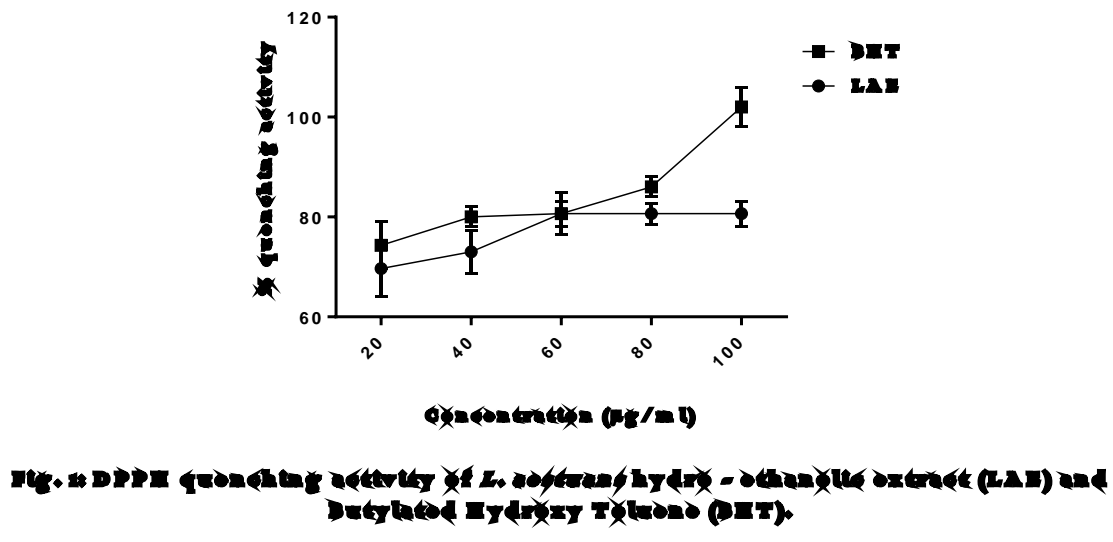

The reduction of the ferric ion $\left(\mathrm{Fe}^{3+}\right)$ to ferrous ion $\left(\mathrm{Fe}^{3+}\right)$ is measured by the intensity of the resultant blue green solution which absorbs at 700nm, an increase in absorbance shows higher reducing power. The dose dependent reducing capacity of LAE was shown in Fig. 2.

It caused a significant elevation of reducing power with OD value of $1.18 \pm 0.015$ at $1000 \mu \mathrm{g} / \mathrm{ml}$ as compared to that of BHT which was $1.130 \pm 031$ at $1000 \mu \mathrm{g} / \mathrm{ml}$. the reducing power of a compound may serve as a significant indicator of its potent antioxidant activity [23].

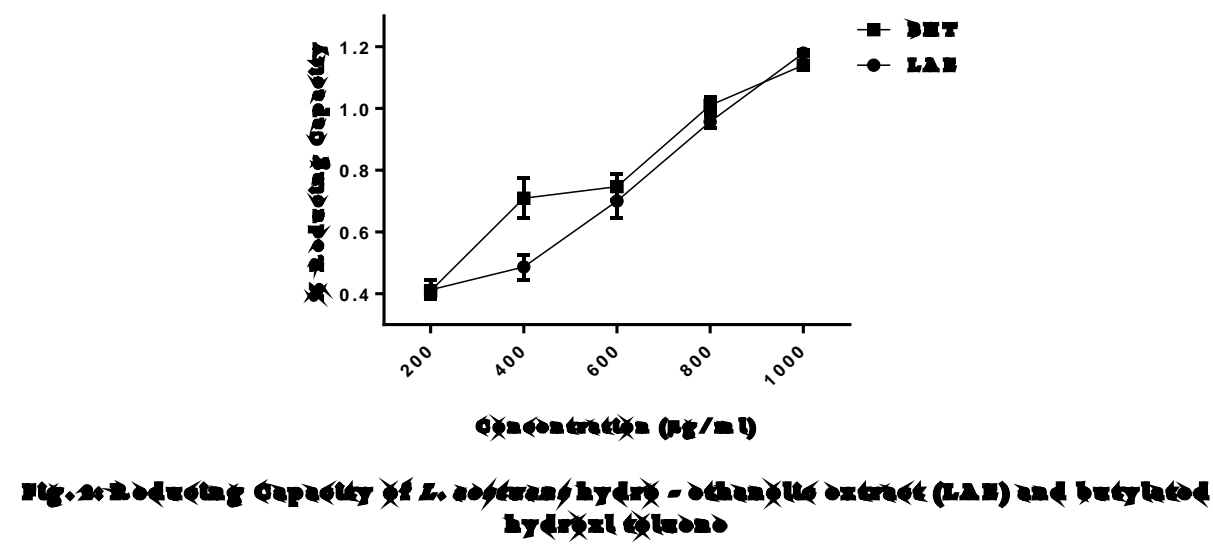

Superoxide radical is the main source for the formation of other ROS such as hydroxyl radical and hydrogen peroxide [24]. Result of the $\mathrm{O}_{2}{ }^{\text {oo }}$ scavenging activity of LAE measured by PMS - NADH - NBT superoxide generating system is shown in Fig. 3. The scavenging effect of extract at a concentration of $500 \mu \mathrm{g} / \mathrm{ml}$ is $79.7 \%$. In the PMS - NADH - NBT system $\mathrm{O}_{2}{ }^{\circ}$ derived from dissolved oxygen by PMS - NADH coupling reaction reduces NBT. The decrease of absorbance at $560 \mathrm{~nm}$ with antioxidants indicates the consumption of $\mathrm{O}_{2}{ }^{\mathrm{oo}}$ in the reaction mixture. The result was comparable with standard BHT which was found to be $80.7 \%$ inhibition at $500 \mu \mathrm{g} / \mathrm{ml}$.

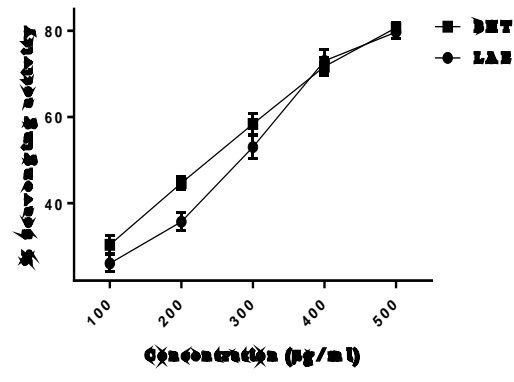

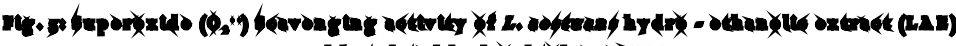

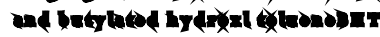


Hydroxyl radicals conjugate with nucleotides in DNA, cause strand breakage and lead to carcinogenesis, mutagenesis and cytotoxicity [25].

The marked antioxidant activity of LAE shown in Fig. 4; scavenged hydroxyl radicals by $71.0 \%$ at $250 \mu \mathrm{g} / \mathrm{ml}$ which is comparable with standard BHT, which showed $73.3 \%$ inhibition at the same concentration.

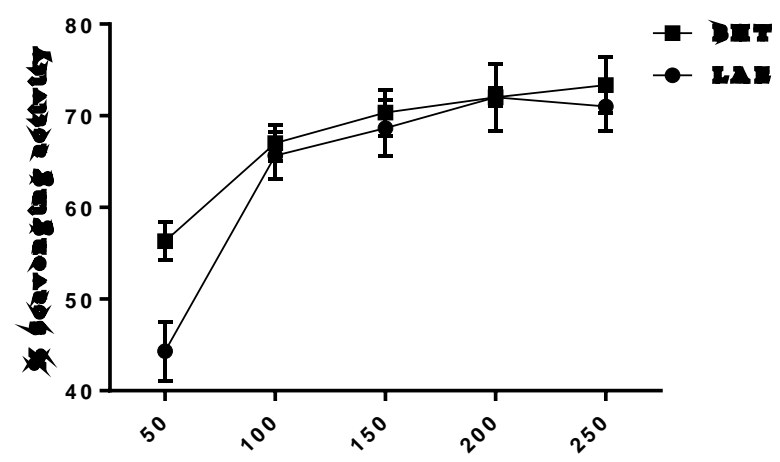

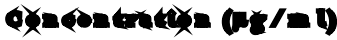

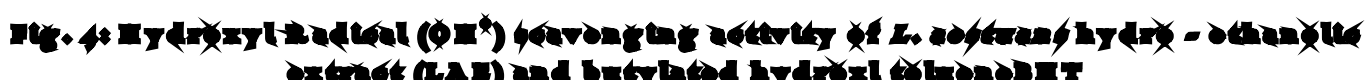

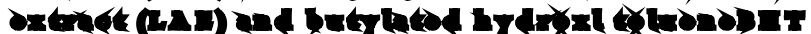

Extent of nitric oxide radical scavenged was determined by the decrease in intensity of pink coloured chromophore at 540nm.

The extract exerted compatible inhibitory $72.7 \%$ potential at the concentration of $250 \mu \mathrm{g} / \mathrm{mg}$ against nitric oxide generation.

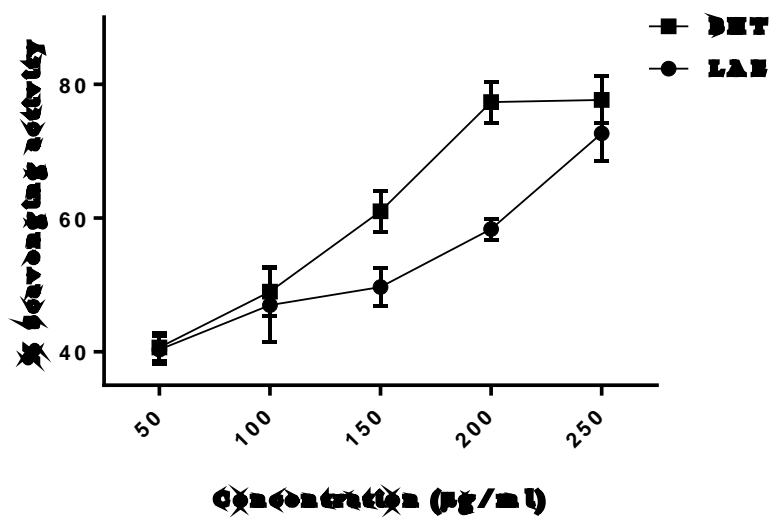

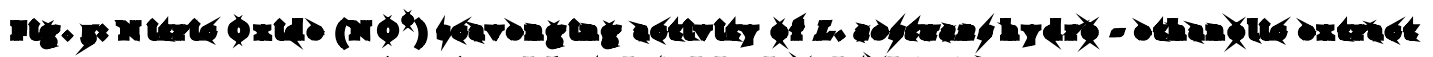

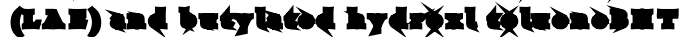

The antioxidant activity was compared with BHT which has $77.7 \%$ inhibition. The study demonstrated the potent nitric oxide scavenging activity of the L. aestuans.

Removal of hydrogen peroxides from cells or food systems is very important for antioxidant defense, since $\mathrm{H}_{2} \mathrm{O}_{2}$ may give rise to hydroxyl radicals which are toxic to cells [26].

Fig. 6 showed that hydrogen peroxide decomposition activity has a concentration dependent pattern. The LAE had $35.0 \%$ at $100 \mu \mathrm{g} / \mathrm{ml}$ and $70.7 \%$ at $500 \mu \mathrm{g} / \mathrm{ml}$; while BHT had $47.3 \%$ at $100 \mu \mathrm{g} / \mathrm{ml}$ and $74.0 \%$ at $500 \mu \mathrm{g} / \mathrm{ml}$. the result showed that the extract possessed inhibition capacity. 


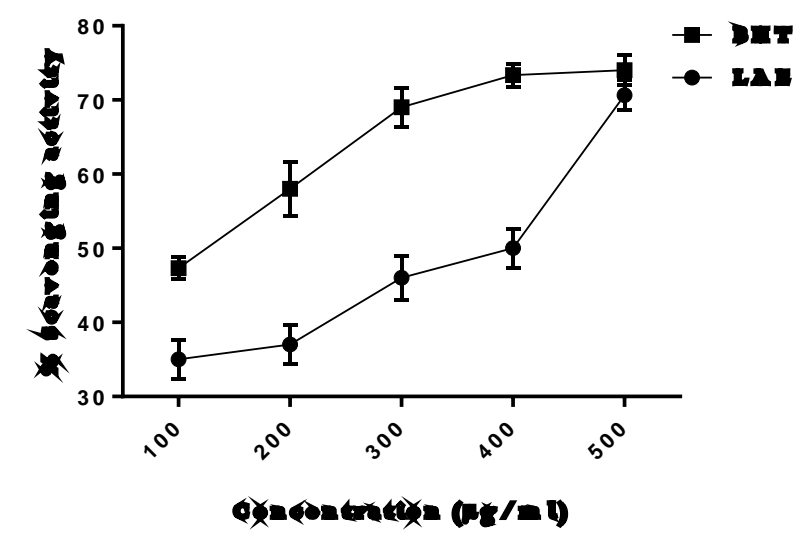

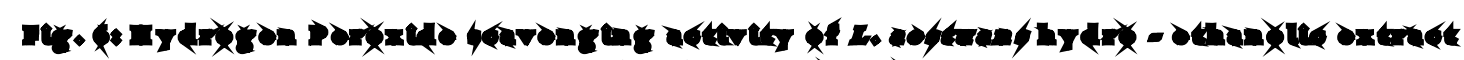

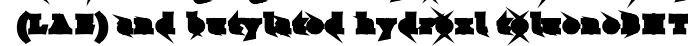

The $\mathrm{ABTS}^{\mathrm{ot}}$ scavenging assay is used to indicate the antioxidant activity of the extract. The LAE demonstrated as an effective scavenger to that of BHT. Fig. 7 showed the extract expressed maximum scavenging activity of $81.3 \%$ as against that of BHT which was $80.7 \%$.

The results are considered to be useful when compared to that of previous studies on medicinal plants [27].

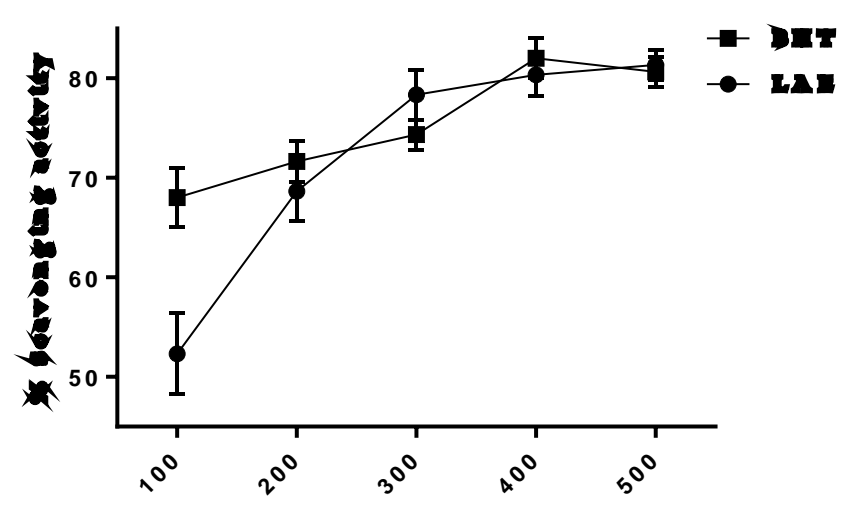

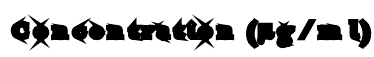

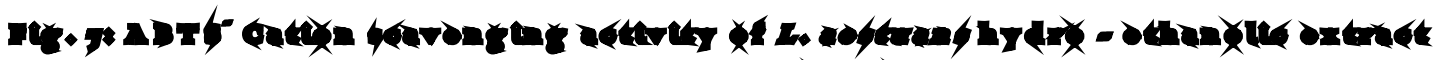

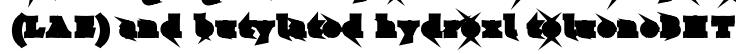

The effect of LAE on peroxidation of lipids in the presence of ferrous sulphate is shown in Fi. 8. It showed an inhibition of $73.7 \%$ at a concentration of $500 \mu \mathrm{g} / \mathrm{ml}$.

The LAE inhibited generation of lipid peroxides in a concentration dependent manner. Therefore, LAE has a strong resistance on peroxidation.

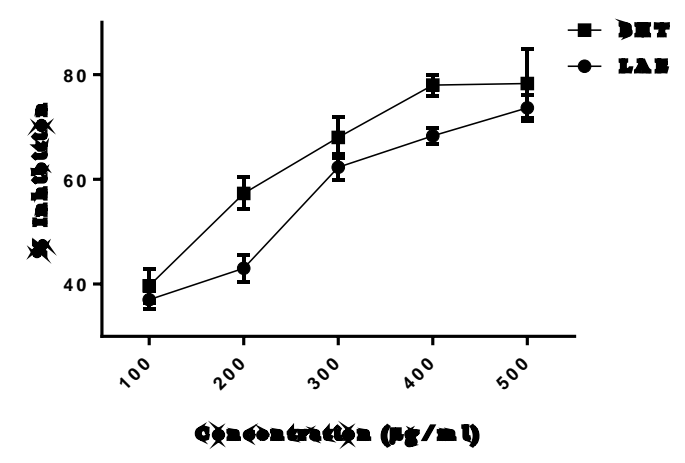

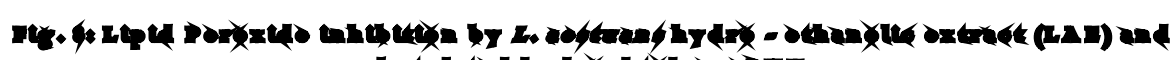




\section{IC50 values and multiple correlations}

Table 2 showed the $\mathrm{IC}_{50}$ values ( $\mu \mathrm{g}$ extract/ml). LAE exhibited IC50 values in DPPH; $\mathrm{O}_{2}{ }^{\mathrm{oo}}, \mathrm{OH}^{\mathrm{o}}, \mathrm{NO}$, $\mathrm{H}_{2} \mathrm{O}_{2}, \mathrm{ABTS}^{\mathrm{O+}}$ and LPO antiradical activities as $15.0 \pm 1.00,247.0 \pm 4.58,84.3 \pm 3.79,67.3 \pm 3.06,230.7$ 7.02, $81.0 \pm 3.61$ and $82.7 \pm 6.43 \mu \mathrm{g} / \mathrm{ml}$ respectively.

DPPH was found to have better inhibiting capacity among all the assays,, with $15.0 \pm 1.00 \mu \mathrm{g} / \mathrm{ml}$. Table 2 also showed the $\mathrm{IC}_{50}$ values of standard BHT.

Table 2: $\mathrm{IC}_{50}$ values of $L$. aestuans Hydro - ethanolic leaf extract (LAE) and standard Butylated Hydroxyl Toluene (BHT)

\begin{tabular}{lll}
\hline Assay models & $\mathbf{I C}_{50} \boldsymbol{\mu g} / \mathbf{m l}$ & \\
\cline { 2 - 3 } & $\mathbf{L A E}$ & $\mathbf{L A E}$ \\
\hline DPPH antiradical activity & $15.0 \pm 1.00^{\mathrm{a}}$ & $11.0 \pm 1.00^{\mathrm{a}}$ \\
$\mathrm{O}_{2}{ }^{\mathrm{o}}$ antiradical activity & $247.0 \pm 4.58^{\mathrm{g}}$ & $57.0 \pm 3.00^{\mathrm{d}}$ \\
$\mathrm{OH}^{\mathrm{o}}$ antiradical activity & $84.3 \pm 3.79^{\mathrm{e}}$ & $45.0 \pm 2.00^{\mathrm{b}}$ \\
$\mathrm{NO}^{\mathrm{b}}$ antiradical activity & $67.3 \pm 3.06^{\mathrm{c}}$ & $34.7 \pm 2.52^{\mathrm{c}}$ \\
$\mathrm{H}_{2} \mathrm{O}_{2}$ antiradical activity & $230.7 \pm 7.02^{\mathrm{f}}$ & $52.3 \pm 5.86^{\mathrm{d}}$ \\
$\mathrm{ABTS}^{\mathrm{o}}$ antiradical activity & $81.0 \pm 3.61^{\mathrm{b}}$ & $42.7 \pm 2.89^{\mathrm{b}}$ \\
LPO inhibition $^{\mathrm{b}}$ & $82.7 \pm 6.43^{\mathrm{d}}$ & $44.3 \pm 3.51^{\mathrm{c}}$ \\
\hline
\end{tabular}

Each value in the table was obtained by calculating the average of three experiments \pm standard deviation ( $\mathrm{n}=3$ ). Values in a column with different superscripts indicate significantly different at $\mathrm{P}<0.05$.

It was observed that a strong correlation exist between total flavonoid $(\mathrm{TF})$ and $\mathrm{ABTS}^{\mathrm{O+}}$ test $\left(\mathrm{R}^{2}=0.982\right)$. Lipid peroxidation and $\mathrm{TF}$ exhibited a perfect correlation $\left(\mathrm{R}^{2}=1.0\right)$. Lower $\mathrm{IC}_{50}$ values indicate higher antioxidant activity of the extracts [28].

Linear regression method was used to demonstrate a direct correlation among the antioxidant test.

\section{Table 3: Correlation coefficient of total phenolic and flavonoids with different} antioxidant assays

\begin{tabular}{lll}
\hline Parameters & TP & TF \\
\hline TP & 1 & \\
TF & 1 & 1 \\
DPPH & 0.832 & 0.848 \\
$\mathbf{O}_{2}$ & 0.986 & 0.986 \\
OH & 0.899 & 0.899 \\
NO & 0.946 & 0.946 \\
RC & 0.988 & 0.988 \\
$\mathbf{H}_{2} \mathbf{O}_{2}$ & 0.936 & 0.938 \\
ABTS & 0.978 & 0.978 \\
LPO & 1 & 0.934 \\
\hline
\end{tabular}

Supportive reports established the positive correlatin between phenolic content and antioxidant activity [29]. A positive correlation between antioxidant activity and polyphenol content was found. This suggests that the antioxidant properties of the plant extract is due to the polyphenols it contains [30]. These results showed that the antioxidant capacity of the leaf extract of L. aestuans is due to the quality of the phenolic compounds and flavonoids it contains.

\section{References}

[1]. G. Kaur, R. Tuli and M. Chintamaneni, "Antioxidant Potential of Methanolic and Hydrolyzed Extracts of Eclipta alba", Pharmacologyonline, vol. 2, pp. 947 - 956, 2009.

[2]. J.C. Espin, C. Soler - Rivas, and H.J. Wichers, "Characterization of the total free radical scavenger capacity of vegetable and oil fractions using 2, 2'-diphenyl-1-picrylhydrazyl radical”. J. Agric. Food Chem., vol. 48, pp. 648 - 656, 2000.

[3]. R.H. Lieu, "Health benefits of fruits and vegetables are from additive and synergistic combination of phytochemicals", Am. $J$. Clin. Nutr., vol. 78, pp. $517-520,2003$.

[4]. R.L. Prior, "Fruits and vegetables in the prevention of cellular oxidative damage". Am. J. Clin. Nutr., vol. 78, pp. 570 - 578, 2003.

[5]. W.L. Chew, "A monograph of Laportea (Urticaceae)". Gard. Bull. Singapore, vol. 21, pp. 178 - $195,1969$.

[6]. I. Cheryl, "Laportea aestuans". J. Ethnobiol. and Medicine, vol. 3, pp. 13, 2007.

[7]. J.F. Morrison, and S.K. Twumasi, "Comparative studies on the in vitro antioxidant properties of methanolic and hydro - ethanolic leafy extracts from eight leafy vegetables of Ghana". Afr. J. Biotech., vol. 9, no. 32, pp. 5177 - 5184, 2010.

[8]. U.A. Essiett, N.I. Edet, and D.N. Bala, "Phytochemical and physiological analysis of leaves of Laportea aestuans (Linn) Chew and Laportea ovalifolia (Schumach) Chew (male and female)". Asian J. Plant Science and Res., vol. 1, no. 2, pp. 35 - 42, 2011. 
[9]. A.A. Sofowora, Medicinal Plants and Traditional Medicine in West Africa, 2nd Edition, John Willey and Sons Ltd. New York, 1993, Pp: 289.

[10]. V.L. Singleton, R. Orthofer, and R.M. Lamuela - Raventos, "Analysis of total phenols and other oxidation substrates and antioxidants by means folinciocalteu reagent method". Enzymol., vol. 299, pp 152 - 178, 1997.

[11]. A.A.L. Ordonez, J.D. Gomez, M.A. Vattuone, and M.J. Isla, “Antioxidant activities of Sechium edule (Jacq) swart extracts". Food Chem., Vol. 9, pp. 452-458, 2006.

[12]. S. Sadasivam and A. Manickan, Biochemical Methods. New Delhi: New-age International (P) Limited, 1996, Pp: 193 - 194.

[13]. R.P. Singh, K.N. Chidambara-Murthy, and G.k. Jayaprakash, "Studies on antioxidant activity of Pomegranate peel and seed extracts using in vitro models". J. Agric. Food Chem., vol. 5, pp.. 86-89, 2002.

[14]. M. Oyaizu, "Studies on product of browning reaction prepared from glucose amine". Jpn. J. Nut., vol. 44, pp. 307 - 315, 1986.

[15]. H. Yu, X. Liu, R. Xing, S. Liu, Z. Guo, P. Wang, C. Li, and P. Li, "In vitro determination of antioxidant activity of proteins from jellyfish Rhopilema esculentum”. Food Chem., vol. 95, pp. 123 - 130, 2006.

[16]. S.M. Klein, G. Cohen, and A.I. Cederbaum, "Production of formaldehyde during metabolism of dimethyl sulfoxide by hydroxyl radical generating systems", Biochemistry Journal, vol. 20, pp. 6006 - 6012, 1981

[17]. D.C. Garret, The Quantitative Analysis of Drugs. $3^{\text {rd }}$ Ed. Chapman and Hall Ltd, Japan, 1964, Pp: 456 - 458.

[18]. R.T. Ruch, S.J. Cheng, and E. Klawnig, "Prevention of cytotoxicity and inhibition of intercellular communication by antioxidants catechins isolated from Chinese green tea". J. Carcinogenesis, vol. 10, pp. $1003-1008,1989$.

[19]. R. Re, N. Pellegrini, A. Proteggente, A. Pannala, M. Yang, and C. Rice-Evans, "Antioxidant activity applying an improved ABTS radical cation decolourization assay". Free Rad. Bio. and Med., vol. 26, pp. 1231 - 1237, 1999.

[20]. G. Ruberto, M.T. Barrata, S.G. Deans, and H.J.D. Dorman, “Antioxidant and antimicrobial activity of Foeniculum vulgarae and Crithumum maritimum essential oils". Planta. Med., vol. 66, pp. 687 - 693, 2000.

[21]. A. Parr and G.P. Bolwell, "Phenols in plant and in man: The potential for possible nutritional enhancement of the diet by modifying the phenol content or profile". J. Sci. Food Agric., vol. 80, pp. $985-1012,2000$.

[22]. L. Bravo, "Polyphenols: Chemistry, dietary sources, metabolism and nutritional significance", Nutr. Rev., vol. 56, pp. 317 - 333, 1998.

[23]. S. Meir, J. Kanner, B. Akiri, and S.P. Hades, "Determination and involvement of aqueous reducing compounds in oxidative defense systems of various senescing leaves". J. Agric. Food Chem., vol. 4, pp. 1813 - 1817, 1995.

[24]. P.G. Pieta, "Flavonoids as antioxidants". J. Nat. Prod., vol. 63, pp. 1035-1042, 2000.

[25]. M.M. Naidu, G. Sulochanamma, S.R. Sampathu, and P. Srinivas, "Studies on extraction and antioxidant potentials of green coffee". Food Chem., vol. 107, pp. 377 - 384, 2008.

[26]. B. Halliwell, "Reactive oxygen species in living systems: sources, biochemistry and role in human disease", Am. J. Med., vol. 9, pp. $14-22,1991$.

[27]. J.M. Sasikumar, V. Maheshu, G.S.|B. Aseervathan, and D..T.P. Darsini, "In vitro antioxidant activity of Hedyotis corymbosa (L) Lam. aerial parts". Indian J. Biochem. Biophy. Vol. 47, pp. 49-52, 2010.

[28]. M.E.G.C. Silva, A.L. Guimaraes, A.P. Oliveira, S. Araujo, J.A.S. Filho, A.P. Fontana, K.F. Damasceno, C.R.C. Branco, A. Branco, and J.R.G.S. Almeida, "HPLC-DAD analysis and antioxidant activity of Hymenaea martiana Hayne (Fabaceae)". J. Chem. and Pharm. Res., vol. 4, no. 2, pp. 1160 - 1166, 2012.

[29]. L. BuØieova and Z. Reblova, "Czech medicinal plants as possible sources of antioxidants", Czech J. Food Sci., vol. 26, pp. 132 138, 2008.

[30]. Y. Kiselova, D. Ivanova, T. Chervenkov, D. Gerova, B. Galunska, and T. Yankova, "Correlation between the in vitro antioxidant activity and polyphenol content of aqueous extracts from Bulgarian herbs". Phythother. Res., vol. 11, pp. 961 - 965, 2006.

\section{BIOGRAPHY}

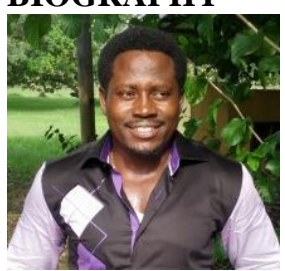

Dr. Okereke Stanley C. was born at Leru in Umunneochi Local Government Area of Abia State, Nigeria on the $23^{\text {rd }}$ November, 1973.

He attended IZZI Community Primary School, Abakaliki, Ebonyi State, Nigeria, where he obtained the first school leaving certificate in 1983. He proceeded to Urban Secondary School Abakaliki, Ebonyi State, and obtained the Senior Secondary School Certificate (SSCE) in 1988. In 1991, he secured admission into Abia State University, Uturu, Abia State and graduated with B.Sc. (Biochemistry) second class upper division in 1996. He obtained M.Sc. (Biochemistry) in 2005 from Michael Okpara University of Agriculture Umudike, Abia State and PhD (Biochemistry) from Abia State University, Uturu, Nigeria in 2012.

He did his National Youth Service Corpe with University of Ilorin, Kwara State as a graduate assistant. He went back to his alma mata, Abia State University, Uturu as a graduate Assistant in 2000, and has remained a faculty member of the Faculty of Biological \& Physical Sciences, Abia State University, Uturu till date. He is currently holding a Lecturer I position in the Department of Biochemistry of the above named school. He has co-authored many journal publications.

Ohiri, R.C., Nwachukwu, N and Okereke, S.C (2007). The Biochemical and Histopathological effects of Chronic cassava based cyanide injection on rat's pancreas. Journal of Research in Bioscience, 3 (3): $64-68$.

Elekwa, I., Okereke, S.C and Ekpo, B.O (2008). Pre;iminary phytochemical analysis and proximate composition of the roots and leaves of Rauwolfia vomitoria. Pakistan Journal of Nutrition, 7 (5): 1 - 3.

Elekwa, I., Okereke, S.C and Ekpo, B.O (2009). Preliminary phytochemical and antimicrobial investigation of the stem bark and leaves of Psidium guajava L. Journal of Medicinal Plant Research, 3 (1): 45 - 48.

Dr. Okereke is a member of Nigeria Society of Biochemistry and Molecular Biology (NSBMB). 